\title{
Egyensúlyfejlesztés játékos mozgásprogrammal hallássérülteknél
}

\section{Equilibrium Development of Hearing-impaired Children with Playful Movement Programs}

\section{Simon-Ugron Ágnes, Boros-Bálint luliana}

Babeș - Bolyai Tudományegyetem, Testnevelés és Sport Kar, Elméleti tantárgyak és mozgásterápia Intézet, Kolozsvár, Románia

Absztrakt: Kutatásunk az egyensúlyfejlesztést vizsgálta hallássérült gyerekeknél. Célunk volt felmérni, hogy az általunk szerkesztett egyensúlyfejlesztésre irányuló játékos mozgásprogram milyen mértékben fejleszti az egyensúlyt a hallássérültek esetében. A vizsgált személyek a kolozsvári Kozmutza Flóra Hallássérültek Speciális Iskolája hallássérült elókészítős osztályok tanulói voltak ( $n=3$ ), F.E. (fiú), LL. (fiú) és T.ZS. (lány). A vizsgálati csoport tagjainak egyensúlyát a Berg-féle Gyermekgyógyászati Egyensúlyskála és a Timed Up \& Go teszt segítségével mértük fel. A csoport tagjai három hónapon keresztül hetente kétszer vettek részt az általunk összeállított játékos mozgásprogramon. Az egyensúly-mérési eredmények megmutatják a játékos mozgásprogram hatékonyságát a hallássérült gyerekeknél. Az egyéni fejlódés 31,25-56,25\% között volt, míg csoport szinten 43,75\%. Öszszegzésként elmondhatjuk, hogy az általunk szerkesztett egyensúlyfejlesztésre irányuló játékos mozgásprogram fejleszti az egyensúlyozási képességet.

Kulcsszavak: egyensúlyfejlesztés, mozgás, hallássérült

\begin{abstract}
Our aim was to investigate the development of balance in hearing-impaired children. We tested the effect of a playful movement-program prepared by us. The subjects were children from the preparatory class of the "Kozmutza Flóra” Special Secondary School for Hearing-impaired in Kolozsvár (Cluj). They were F.E. (boy), L.L. (boy) and T.ZS. (girl). The group's balance was measured with the Paediatric Balance Scale after Berg and with the "Timed Up \& Go" test. The members of the studied group participated in the playful movement-program twice a week for three months. The equilibrium measurement research shows the effectiveness of the playful movement-program in the children with hearing impairment. The individual improvement was between $31.25 \%-56.25 \%$ and in the group $43.75 \%$. Finally, it can be concluded that the playful movement-program developed by us improves the capacity of equilibrium of children with hearing impairment.
\end{abstract}

Keywords: equilibrium development, movement, hearing impairment

\section{Bevezetés}

A hallásérzékelés rendkívül összetett folyamat, amely bármelyik szakaszában megszakítást szenvedhet. A hallássérülés megfogalmazás gyüjtőnév, ide sorolható a halláskárosodás minden típusa és foka (Csanádi, 1998; Hoffman \& Mezeiné, 2006; Dolfi, 2014).

Napjainkban a halláskárosodást tartják a világon a legnagyobb számban jelen lévő érzékveszteségnek. Közel 600 millió ember, a népesség kb. 10\%-a, rendelkezik enyhe vagy súlyos halláskárosodással, amelyből 250 millió közepesen vagy súlyosan hallássérült. A Hear-it.com 2011-es kiadása alapján Adrian Davis, a brit MRC Halláskutató Intézet (MRC Institute of Hearing Research) professzora, becslése szerint a $25 \mathrm{~dB}$-nél nagyobb hallássérült emberek száma 2015-re a 700 milliót is meghaladhatja, valamint becslések szerint 2025-re a világon 900 millió hallássérült fog élni, amelyből 90 millió európai lesz (Traynor, 2011).

$\mathrm{Az}$ egyensúlyfejlesztés Pappné Gazdag Zsuzsanna (2009) szerint három lépésből áll: az 
ingerek megtanulásából, az ingerekre adott válaszadás kidolgozásából és az egyensúly megtartásának tanulásából.

$\mathrm{Az}$ ingerek megtanulása képezi az első és legalapvetőbb szakaszt. Ez már a bölcsőben ringó gyermeknél kezdetét veszi, amikor a ritmikus oda-viszsza ringástól az ívjáratokban levő folyadék a járatok falához csapódik, ahol az érzékelő sejtek vannak. Az újra meg újra megérintett érzékelő sejtek jelzéseket küldenek az agyba. A sokszori ismétlődés az idegpályák bejáratódását eredményezi. Ez a folyamat megy végbe hintázás során is.

A második lépés az ingerekre adott válaszadás kidolgozásából áll, amikor az egyensúlyából kibillent(ett) test az egyensúly megtartására vagy annak visszaszerzésére törekszik. Ez történik járástanulás közben, lépcsőre fel-le járáskor, ahol a súlypont áthelyezése még kihívást jelent a gyermek számára.

Az egyensúly megtartásának tanulása a harmadik szakasz, ahol a gyerek az egyensúly fenntartására törekszik az intenzívebb haladással járó gyakorlatoknál (Pappné, 2009).

Minden olyan gyakorlat, amely a súlypont helyzetének megváltozásával jár, egyensúlyfejlesztő gyakorlatnak tekinthető, mert egyensúlybontással jár. A fejlesztés célja az idegsejtek közötti kapcsolatok kialakítása, valamint az idegpályák bejáratása. Minél jártasabb a gyermek az egyensúlyérzékelésben és a motoros válaszadásban, annál hamarabb szerzi vissza az egyensúlyát. Ehhez azonban rengeteg egyensúlybontással járó gyakorlatra van szükség. Fejlettebb egyensúlytartás esetén erőteljesebb kimozdító beavatkozásra van szükség.

Az egyensúly megtartásának megtanulásánál a kisebb mozdulatok mindig a nagyobb kiterjedésűekre épülnek. Mozgás közben minél mélyebben található a gyermek súlypontja, annál biztosabb az egyensúlyi helyzete. Ahhoz, hogy a fejlesztés sikeresebb legyen, szükséges betartanunk néhány elvet. A legfontosabb a fokozatosság elve, ami abban nyilvánul meg, hogy mindig a nagyobb alátámasztási felületen végzett gyakorlatokkal kell kezdeni, majd azokat fokozatosan csökkenteni. A helyváltoztató feladatok elött helyzetváltoztató gyakorlatokat hajtsanak végre a diákok. Ezeket először előre, oldalra, majd hátrafele haladással is gyakorolják. A felhasznált tornaszerek magasságát és meredekségét is fokozatosan emeljük. Előbb talajon végeztessük a feladatot, majd tornaszeren, végül pedig ezek magasításával. Bizonyos idő elteltével a gyakorlatok végrehajtási tempóját is fokozzuk, ezáltal is növelve a fejlesztés hatásfokát. Ugyanakkor a feladatok végrehajtásánál fontos szerepet játszik a változatos eszközhasználat és a megfelelő ismétlésszám is. A már ismert eszközök változatos használata motivációt nyújthat a gyermekeknek. Újabb kihívásoknak tehetjük ki őket az ismerős gyakorlatok új körülmények közötti végeztetésével, így téve még érdekesebbé a gyakorlást. A gyakorlatokat sokszor kell végrehajtatni ahhoz, hogy kialakuljon az automatizmus, amikor a diák már nem a körülményekre koncentrál, hanem magára a feladatra.

Ellenjavallott az egyensúlyrendszer túlingerlése hosszan tartó forgómozgásokkal. Javasolt viszont játékos próbák, feladatok kitalálása/kialakítása a megfelelő motiváció fenntartása érdekében. A segítségadás mértéke a lehető legkisebb legyen, mert a gyermek az önálló tevékenység során fejlődik a legjobban (Pappné, 2009).

Az egyensúlyfeladatok nemcsak az egyensúlyérzéket fejlesztik, tökéletesítik, hanem a nagy mozgásmintákat, az önvédelmi reflexeket, térbeli észlelést és megjelenítést is. Ezzel egy időben növelik a bátorságot, önuralmat, figyelmet és lélekjelenlétet is. Ez a hallássérültek esetében is jól észrevehető.

Célunk volt felmérni, hogy az általunk szerkesztett egyensúlyfejlesztésre irányuló játékos mozgásprogram milyen mértékben fejleszti az egyensúlyozási képességet a hallássérülteknél.

\section{Módszerek}

A kutatás esettanulmány formájában zajlott 2015 novembere és 2016 márciusa között. A vizsgált személyeket a Kozmutza Flóra Hallássérültek Speciális Iskolája hallássérült előkészítős osztályából választottuk ki. L.L.(fiú) és T.ZS. (lány) bilaterális súlyos hallásveszteséggel rendelkezik, F.E. (fiú) súlyos halláscsökkenéssel él, amihez epilepszia és értelmi fogyatékosság is társul.

A kutatási csoport tagjai három hónapon keresztül hetente kétszer vettek részt az általunk összeállított játékos mozgásprogramon az iskola tornatermében. A kutatás során a következő vizsgálati módszereket alkalmaztuk: szakirodalmi és statisztikai adatgyüjtés, megfigyelés, adatfeldolgozás és elemzés. A vizsgált személyek egyensúlyát a Berg-féle Gyermekgyógyászati Egyensúlyskála (Franjoine, Gunther, \& Taylor, 2003) és a Timed Up \& Go teszt (Brown, 2012) segítségével mértük fel. 
A Berg-féle Gyermekgyógyászati Egyensúlyskála $14 \mathrm{db}$ egyensúlymérő teszt összessége, amelyet specifikusan gyerekek mérésére dolgoztak ki. A teszt elején felsorolják a felméréshez szükséges eszközöket, majd utasítást adnak az egyensúlygyakorlatok végrahajtására. Az értékelés egy 0 -tól 4-es skálán történik. Némelyik feladat pontozásánál a gyakorlat elvégzéséhez szükséges időt is figyelembe kell venni. A maximális elérhető pontszám 56 . A kapott értékeket összehasonlítottuk a velük egykorú egészséges gyerekek adataival (Ramstrand \& Ramstrand, 2007) és ezek alapján választottuk ki a három személyből álló vizsgálati csoportot. A következőkben feltüntetjük a vizsgált személyek Berg-féle Gyermekgyógyászati Egyensúlyskálán elért pontszámait az egészséges gyerekek pontszámainak átlagaival összevetve: F.E. (8,46 éves életkorú) 40 pontot ért el 55,2 helyett; L.L. (6,5 éves) 44 pontot ért el 53,8 helyett, míg T.ZS (7,11 éves) 46-ot 55,2 helyett.

A Timed Up \& Go tesztet (TUG) régebben a dinamikus egyensúly felmérésére használták, és a közösségben élő idős emberek elesése kockázatának előrejelzéseként szolgált. A teszt abból áll, hogy jelre egy széken ülő páciens feláll a székről, sétál 3 métert előre, megkerül egy bóját, majd visszasétál, és újból elfoglalja a helyét (Brown, 2012). Ez a tevékenység ahhoz hasonlítható, amikor egy osztályteremben a tanár kihívja a diákot a táblához. Az első felméréskor a vizsgált személyek a következő eredményeket érték el: F.E. 7,46 sec; L.L. 6 sec; míg T.ZS. 10,35 sec.

$\mathrm{Az}$ alkalmazott mozgásprogramok célkitüzése elsősorban az egyensúly, valamint a nagy mozgásminták fejlesztése, szociális képességek kialakítása, illetve a figyelem és koncentrációs készség növelése.

A kutatás során nyolc mozgásprogramot alkalmaztunk, amelyek közül az első hármat mutatjuk be.

\section{Mozgásprogram}

"Talphinta": alapállás, karlendítéssel előre emelkedés lábujjra, majd karlendítéssel hátra sarokra. Folyamatosan testsúly-áthelyezéssel.

"Bölcsö": hanyatt fekve egy szőnyegen vagy izolíron (polifoamon) a felhúzott térdeket átölelve hintázás jobbra-balra, előre-hátra.

"Csónakringás": szőnyegen vagy izolíron hason fekvésből gurulás jobb-, majd baloldalra, ujjfüzéssel magas tartásban.

"Kelj fel, Jancsi": nyújtott ülés szőnyegen vagy izolíron. Egyik láb nyújtva, a másik a térdben hajlítva, karral a nyújtott térdet átkarolva. A nyújtott lábbal lendületet véve előre-hátra hintázás ülésből hanyattfekvésbe folyamatosan.

„Verébszökdelés”: szökdelés zárt lábbal egy helyben.

"Fatörzsguritás": szőnyegen vagy izolíron hason fekvés, magas tartásban ujjfüzés. Gurulás a test hossztengelye körül.

„Kiskutyamászás”: mászás térdelőtámaszban, előre, hátra, oldalra is.

„Elefántjárás”: járás előre és hátra négykézláb (tenyéren és talpon), azonos oldali végtagok együttlépésével. Testsúlyáthelyezéssel jobbra, balra.

"Tevejárás": járás négykézláb, nyújtott karral és térddel. Ellentétes kar- és lábmunkával.

„Katonakúszás”: kúszás hason, ellentétes kar- és lábmunkával. Tenyérrel előrehúzva a testet. Előre, hátra és szlalomban is.

„Bicebóca”: futás előre és hátra a pad mellett haladva, egyik lábbal a padon, másikkal a talajon. Mindkét oldalra végrehajtva.

„Pingvinjárás": járás a tér minden irányába, kifelé fordított lábfejjel, teljes talpon, testsúlyáthelyezéssel egyik lábról a másikra, elöre néző tenyérrel.

"Gólyajárás": járás a tér minden irányába, oldalsó középtartással váltott térdemeléssel vízszintesig.

\section{Mozgásprogram}

„Talphinta" padon: alapállás padon, karlendítéssel elöre emelkedés lábujjra, majd karlendítéssel hátra sarokra. Folyamatosan testsúly-áthelyezéssel.

„Verébszökdelés” karikákba: szökdelés zárt lábbal különböző színủ karikákba.

„Pingvinjárás" padon: járás a tornapadon, kifele fordított lábfejjel, teljes talpon, testsúly-áthelyezéssel egyik lábról a másikra, előre néző tenyérrel.

„Gólyajárás"két padon: járás a tornapadon, oldalsó középtartással, váltott térdemeléssel vízszintesig.

„Kiskutyamászás” párosával: mászás térdelőtámaszban egy izolíron vagy szőnyegen párosával úgy, hogy a hátul lévő gyermek megfogja az előtte lévő bokáját.

„Fatörzsguritás" párosával: szőnyegen vagy izolíron hason fekvés párosával, magas tartásban egymás kezének megfogása. Gurulás a test hossztengelye körül.

„Akadálypálya”: a gyerekek jelre elindulnak lábujjhegyen vagy sarkon a falra kétoldalt kifeszített kötelekig, utána katonakúszás a kötelek alatt. A pálya végén el kell venni egy kisebb gumilabdát, viszszakúszni a kötelek alatt, majd futás a pálya elején 
egymással egy vonalban elhelyezett karikákig. Az nyer, aki a leghamarabb odaér a saját karikájához.

\section{Mozgásprogram}

„Verébszökdelés” karikába váltott lábon: szökdelés váltott lábbal különböző színű kör alakba rendezett karikákba.

„Gólyajárás" padon a bordásfal mellett: járás a tornapadon a bordásfal mellett, oldalsó középtartással, váltott térdemeléssel vízszintesig, a bordásfalból kiálló botok fölött átlépéssel.

„Kiskutyamászás" döntött padon: mászás térdelőtámaszban egy bordásfalra felhelyezett és megdöntött padon felfele, majd lefele.

„Katonakúszás" kötéllel: kúszás hason, ellentétes kar- és lábmunkával egy a bordásfal alsó fokára kötött hosszú kötélen húzódzkodás segítségével.

„Fatörzsguritás" párosával: szőnyegen vagy izolíron hason fekvés párosával, magas tartásban egymás kezének megfogása, térdek között egy-egy gumilabdával. Gurulás a test hossztengelye körül a labda elhagyása nélkül.

„Akadálypálya”: a gyerekek jelre elindulnak lábujjhegyen vagy sarkon a falra kétoldalt kifeszített kötelekig, utána katonakúszás a kötelek alatt. A pálya végén el kell venni egy kisebb gumilabdát, viszszakúszni a kötelek alatt, majd futás a pálya elején egymással egy vonalban elhelyezett karikákig. Az nyer, aki a leghamarabb odaér a saját karikájához.
„Uborkalépés” karikán: uborkalépés színes karikán, lelépés nélkül.

„Egyensúlylabdázás”: alapállás egyensúlykorongon labda elkapásával/eldobásával, anélkül, hogy lelépne az egyensúlykorongról.

„Kiskutyamászás, pingvinjárás és gólyajárás akadálypályája”: mászás térdelőtámaszban két tornapad közé elhelyezett traktorgumi nagyságú színes műanyag hengereken keresztül, majd felállás az egyik tornapadra és járás a tornapadon, kifelé fordított lábfejjel, teljes talpon, testsúly-áthelyezéssel egyik lábról a másikra, miközben a tenyér előre néz, majd a táv megtételével leugrás és felállás a második padra, amin gólyajárás következik (járás a tornapadon, oldalsó középtartással, váltott térdemeléssel vízszintesig).

\section{Eredmények}

A Berg-féle Egyensúlyskála szerinti elsö és utolsó felmérés eredményei

Az első ábrán az figyelhető meg, hogy F.E. az 1., 4., 6., 7., 11., 13. és 14. részteszteken már a kezdetben maximálisan teljesít, míg a 8. résztesztnél 0-ról 3 pontra emeli az eredményét, valamint a többi résztesztnél, a 9. kivételével, a közös mozgásprogram végére sikerül elérnie a legmagasabb pontszámot.

\section{F.E. Berg-féle Egyensúlyskála szerinti első és utolsó felmérési eredményeinek összehasonlítása}

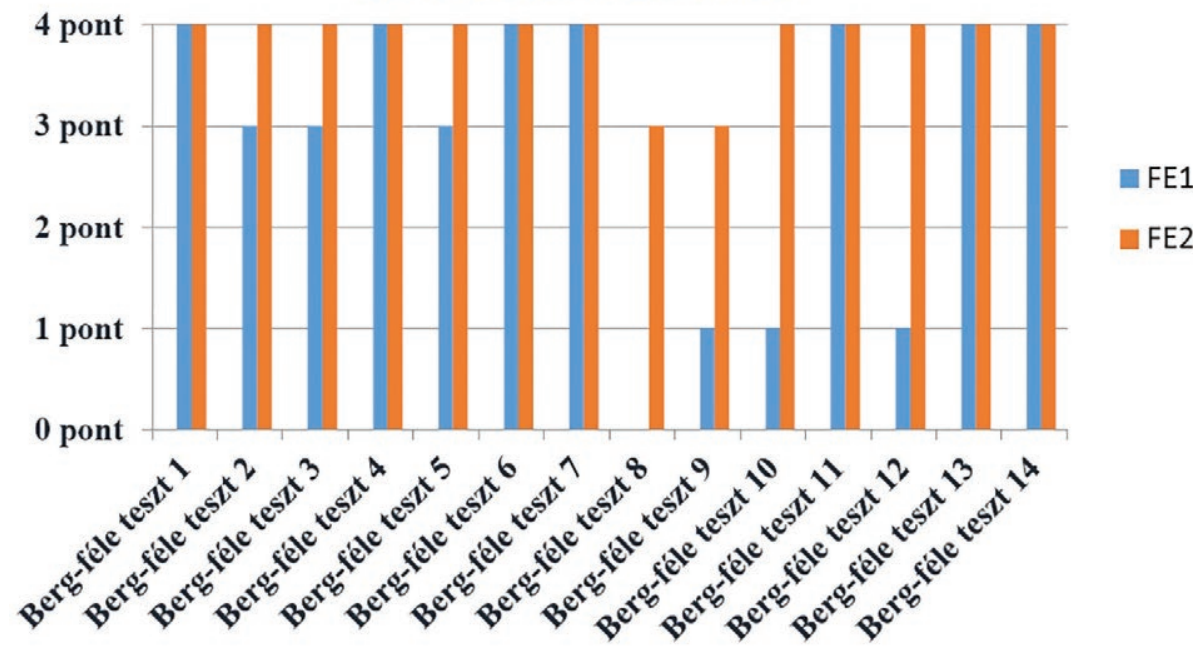

1. ábra. F.E. eredményei [Forrás: saját szerkesztés] 
L.L. (2. ábra), amíg a legtöbb teszten fenntartja a maximális eredményt már a mozgásprogram kezdetétől fogva, addig az 5-7. és 12. próbákon megnöveli pontszámát 1-3 pontról 4-re, a 8. számú résztesztet pedig két hónap után hibátlanul hajtja végre.

\section{L.L. Berg-féle Egyensúlyskála szerinti első és utolsó felmérési eredményeinek}

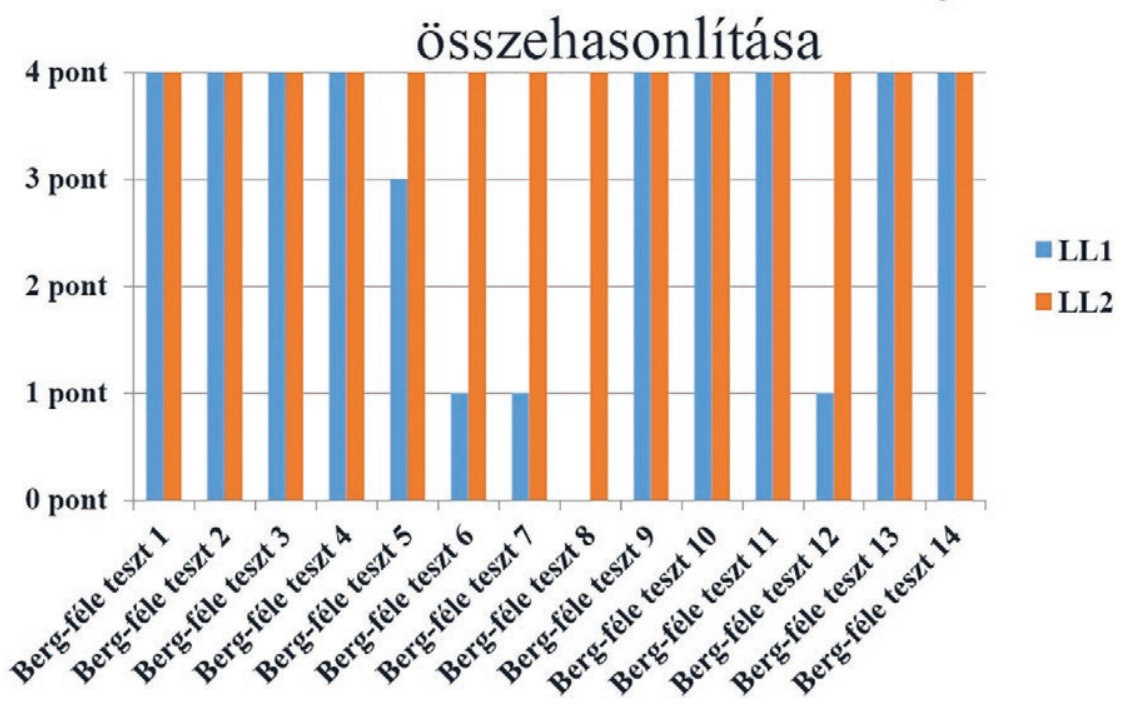

2. ábra. L.L. eredményei [Forrás: saját szerkesztés]

T.Zs-nek (3. ábra) a résztesztek nagy részénél mindvégig megmarad a maximális pontszáma, a 2., 3., 9., 11., 12. próbáknál felemeli 4-re a pontszámát, viszont a 8 . résztesztnél enyhe visszaesés figyelhető meg, mivel itt 4-ről 3 pontra csökken a teljesítményének a mértéke.

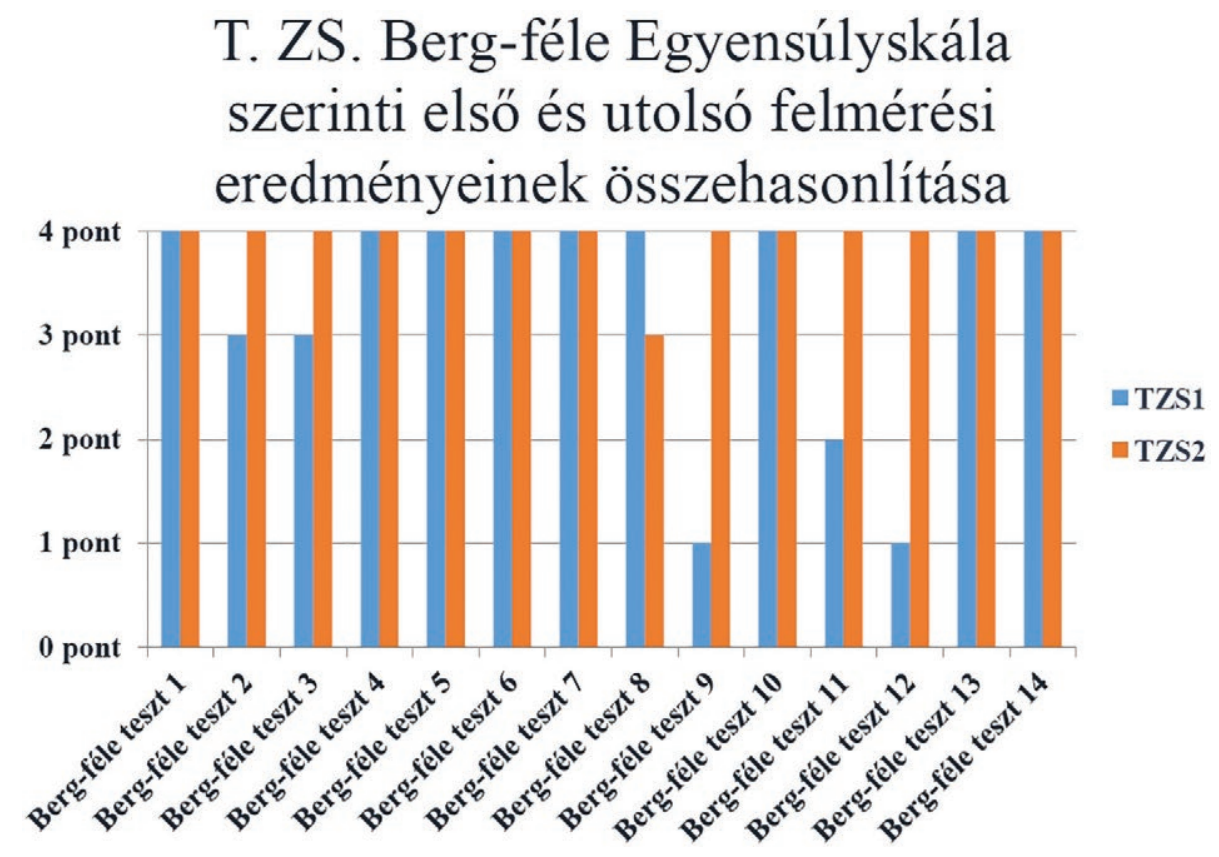

3. ábra. T.ZS. eredményei [Forrás: saját szerkesztés] 


\section{A Timed Up \& Go teszt eredményei}

F.E. TUG első és utolsó felmérési eredményeinek összehasonlítása

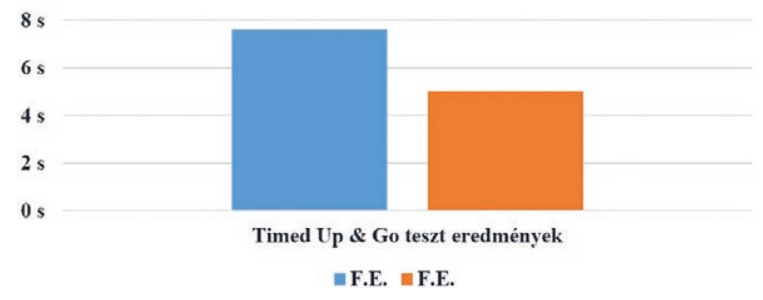

4. ábra. F.E. eredményei [Forrás: saját szerkesztés]

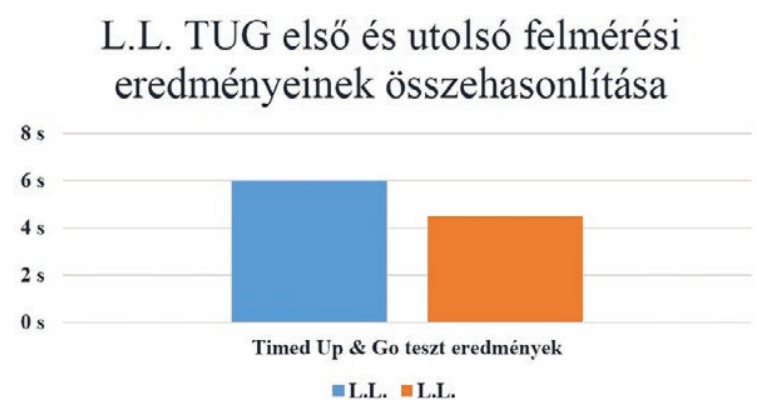

5. ábra. L.L. eredményei [Forrás: saját szerkesztés]

\section{T.ZS. TUG első és utolsó felmérési eredményeinek összehasonlítása}

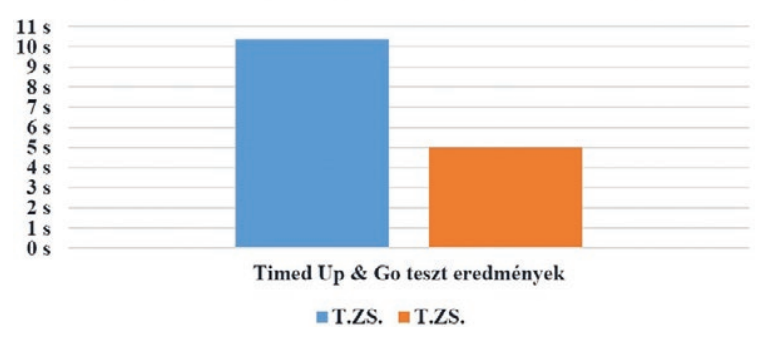

6. ábra. T.ZS. eredményei [Forrás: saját szerkesztés]

A Timed Up \& Go teszt esetében a legnagyobb fejlődés T.Zs.-nél volt megfigyelhetö, aki 10,35-ről 5 másodpercre csökkentette a feladatsor végrehajtási idejét. A kutatás során a mozgásprogramunk egyensúlyfejlesztési hatékonyságát figyelhettük meg a hallássérülteknél. Ez egyénileg 31,25-56,25\%-os javulást mutatott, ami csoport szinten 43,75\%-os teljesítményjavulást jelent.

\section{Következtetések}

$\mathrm{Az}$ általunk összeállított egyensúlyfejlesztésre irányuló játékos mozgásprogram tehát fejleszti az egyensúlyozási képességet. A vizsgált személyek alacsony száma miatt további kutatásra van szükség programunk eredményességének tesztelésére.

\section{Irodalom}

1. Brown, K. (2012): Use of the Pediatric TUG Outcome Measure in School-aged Children with the Diagnosis of Down's Syndrome. Carroll University Library. Physical Therapy Case Study Collection. http://digitalcollections.carrollu. $\mathrm{edu} / \mathrm{cdm} / \mathrm{ref} /$ collection/ptthesis/id/132 (Letöltés: 2015. április 23.)

2. Csanádi Gabriella (1998): Bevezetés a korai fejlesztés gondozás témaköreibe. Comenius Kft., Pécs.

3. Dolfi Alexandra (2014). Hipoacuzia neurosenzorială (de perceptie). http://www. romedic.ro/hipoacuzia-neurosenzoriala-deperceptie (Letöltés: 2015. március 27.)

4. Franjoine Mary Rose, Gunther Joan S. \& Taylor Mary Jean (2003). Pediatric Balance Scale: A Modified Version of the Berg Balance Scale for the School-Age Child with Mild to Moderate Motor Impairment. Pediatric Physical Therapy, 15(2): 114-128.

5. Hoffmann Judit és Mezeiné Isépy Mária (2006): Gyógypedagógiai alapismeretek. Comenius Kft., Pécs.

6. Pappné Gazdag Zsuzsanna (2009): Egyensúlyozás. Koordinációs kompetenciák fejlesztése. Flaccus Kiadó, Győr.

7. Ramstrand, N. és Ramstrand, S. (2007): The Effect of Ankle Foot Orthoses on Balance. American Board for Certification in Orthotics Prosthetics \& Pedorthics $(A B C)$. Practice analysis of certified practitioners in the disciplines of orthotics and prosthetics. http://www.oandp. org/olc/lessons/html/SSC_10/section_30. asp?frmCourseSectionId=42190E1B-0032486E-BBD4-A024113C640D (Letöltés: 2015. október 26.)

8. Traynor, R. (2011): The Incidence of Hearing Loss Around the World. Hearing Health \& Technology Matters. http:// hearinghealthmatters.org/ (Letöltés: 2015. március 27.) 